\title{
EFFECT OF SOME CHEMICALS ON SPERMATOGENESIS IN RHESUS MONKEYS*
}

\author{
AMIYA B. KAR, V. P. KAMBOJ AND HARISH GHANDRA
}

Central Drug Research Institute, Lucknow, India

(Received 7th fune 1967)

\begin{abstract}
Summary. Antispermatogenic effect of Methallibure (ICI 33828), Tretamine (triethylenemelamine) and Busulphan (1,4-dimethanesulphonoxybutane) was investigated in rhesus monkeys. Methallibure ( $16 \mathrm{mg} / \mathrm{kg}$ for 15 days, orally) had no effect on spermatogenesis, Leydig cells or pituitary gonadotrophic activity. Tretamine $(0.05 \mathrm{mg} / \mathrm{kg}$ for 30 days, intravenous injection) selectively arrested spermatogenesis at the spermatogonial stage and caused a slight reduction in serum gonadotrophin level. Busulphan (10 $\mathrm{mg} / \mathrm{kg}$, single intraperitoneal injection) also suppressed spermatogenesis at the spermatogonial stage but not selectively, since an adverse effect on the interstitium and the accessory genital organs was noted; some reduction in serum gonadotrophin content was also observed. These effects appeared to be reversible. The possible significance of these findings in relation to the modus operandi of these compounds is discussed.
\end{abstract}

\section{INTRODUCTION}

This paper records the effect of Methallibure (1- $\alpha$-methylallylthiocarbamoyl-2methyl-thiocarbamoylhydrazine, IGI 33828), triethylenemelamine (Tretamine) and 1,4-dimethanesulphonoxy butane (Busulphan, Myleran) on spermatogenesis in adult rhesus monkeys (Macaca mulatta).

Methallibure has been reported to suppress the oestrous cycle in rats and menstruation in rhesus monkeys through an inhibition of pituitary gonadotrophic activity (Paget, Walpole \& Richardson, 1961). A reduction in urinary excretion of pituitary gonadotrophin has been observed in post-menopausal cases, in women of reproductive age and in men with prostatic carcinoma (Walpole, 1965). In male rats, spermatogenesis is arrested at the primary spermatocyte stage and fertility is reduced; the weight of the accessory genital organs and gonadotrophin content of the pituitary are appreciably decreased (Paget et al., 1961; Walpole, 1965; Nelson \& Patanelli, 1965). Spermatogenic arrest and loss of weight of the genital organs have also been recorded in dogs presumably through suppression of pituitary gonadotrophic function (Paget et al., 1961).

The radiomimetic agent Tretamine induces and maintains sterility in male rats when administered in small doses. A brief phase of sterility is observed 20 to

\footnotetext{
* Communication No. 1166 from the Central Drug Research Institute, Lucknow, India.
} 
25 days after treatment without any apparent histological changes in the testis (Bock \& Jackson, 1957). Such antifertility effect is believed to be due to intrauterine death of foetuses and pre-implantation ova in females inseminated by males treated with this compound (Steinberger, Nelson, Boccabella \& Dixon, 1959). Higher doses produce a biphasic sterility pattern (Bock \& Jackson, 1957) and destruction of spermatogonia followed by maturation depletion of the seminiferous epithelium (Steinberger et al., 1959). In dogs, intravenous infusion in small doses causes arrest of spermatogenesis with desquamation and pyknosis of the seminiferous epithelial elements and formation of multinucleate giant cells (Hendry, Homer, Rose \& Walpole, 1951).

A single intraperitoneal injection of Busulphan has been reported to cause reversible sterility in rats after about 9 weeks due to an inhibition of spermatogonial development followed by depletion of the seminiferous epithelium by maturation (Jackson, Fox \& Craig, 1961). There is, however, no effect on androgenic function of the testes (Jackson et al., 1961) but the total gonadotrophin content of the pituitary is reduced (Kar, Jehan, Kamboj, Chowdhury \& Chowdhury, 1967). The biochemical composition of the whole testis (Ahlquist, 1966) or separated seminiferous tubules (Kar et al., 1968) is also altered.

\section{MATERIAL AND METHODS}

Adult male rhesus monkeys of the Institute primate colony weighing 7 to $10 \mathrm{~kg}$ were used in this investigation. The mice ( 6 to $8 \mathrm{~g}$ ) were of a Swiss strain maintained at the Institute colony. The animals were kept in air-conditioned quarters (temperature $75 \pm 2^{\circ} \mathrm{F}$ ) under uniform husbandry conditions throughout the experimental period.

Methallibure was administered orally at the rate of $16 \mathrm{mg} / \mathrm{kg}$ daily for 15 days. Tretamine was injected intravenously at a dose of $0.05 \mathrm{mg} / \mathrm{kg}$ daily for 30 days. Busulphan was given by the intraperitoneal route $(10 \mathrm{mg} / \mathrm{kg}$, a single injection). Methallibure and Busulphan were macerated with an equal quantity of gum acacia and suspended in distilled water. Control animals received the respective vehicle alone in a similar manner.

Monkeys treated with Methallibure and Tretamine were killed $24 \mathrm{hr}$ after the last feeding or injection; animals receiving Busulphan were killed 30, 40 and 70 days after injection. The genital organs and the pituitary were dissected out and weighed accurately. Tissues were fixed in Bouin's fluid and serial paraffin sections were stained with Ehrlich's haematoxylin and eosin. Fructose concentration of the seminal vesicles was estimated by the method of Mann (1946) and prostatic acid phosphatase activity by the technique of Hawk, Oser \& Summerson (1954).

Total gonadotrophin content of the pituitary and serum was measured by the immature mouse uterine weight method according to the procedure of Kar \& Datta (1965).

\section{RESULTS}

Methallibure had no appreciable effect on testis weight, a diminished trend was noticed after Tretamine administration, but Busulphan caused a marked 


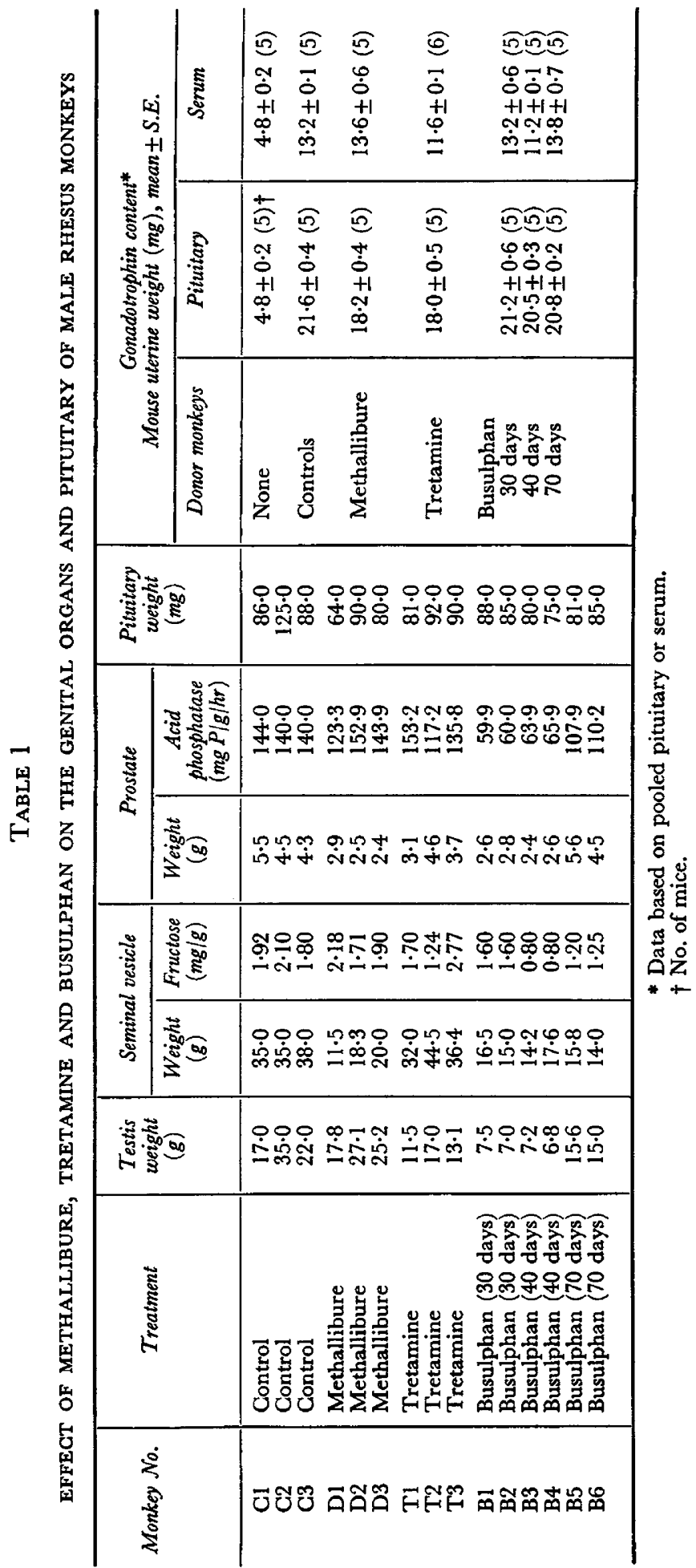


reduction at 30 and 40 days after treatment; at 70 days the weight of the organ recorded a relative increase (Table 1). Histologically, the testis of control monkeys presented typical adult features with successive stages of transformation of the seminiferous epithelium into spermatozoa (Pl. 1, Fig. 1). The tunica propria was normal and prominent. The interstitium contained Leydig cells and fibroblast-like elements and vascularity was normal. Methallibure had no effect on the histological picture of the testis.

The diameter of the tubules was somewhat reduced in Tretamine-treated animals. Spermatogenesis was arrested at the spermatogonial stage and the tubules were almost depleted except for these elements and Sertoli cells (Pl. 1, Fig. 2). In a few tubules some spermatids and spermatozoa were observed which were evidently in the process of depletion; in others, a debris of desquamated epithelial elements was noticed. The tunica propria, interstitium and the vascularity were, however, normal.

The tubules of Busulphan-treated monkeys examined 30 and 40 days after injection were shrunken and infantile (Pl. 1, Fig. 3). The seminiferous epithelium consisted of a few spermatogonia and mostly Sertoli cells; other stages were prominently absent except for occasional spermatids. The integrity of the tunica propria was lost and the tubules were lined by a layer of fusiform cells with dark-stained nuclei. In the interstitium there was a preponderance of fibroblast-like elements over the Leydig cells. Some of the latter appeared normal but many atrophied ones were also encountered. The vascularity of the organ was reduced.

At 70 days after Busulphan treatment the tubular diameter was increased. The seminiferous epithelium contained many new spermatogonia, some of which were dividing; occasional resting primary spermatocytes could be discerned in some tubules. The tunica propria was normal. In the interstitium the preponderance of fibroblast-like elements was no longer noticeable and the presence of normal Leydig cells was a consistent feature. The vascularity of the organ was normal.

The weight of the seminal vesicles showed some reduction in the Methallibure group, but was consistently depressed in the Busulphan-treated animals; Tretamine had no effect (Table 1). In general, the fructose concentration of the seminal vesicles did not register any noteworthy alterations except for a reduction in the Busulphan (40 days) group. The prostatic weight was lowered after Methallibure and Busulphan (30 and 40 days) administration; in the Tretamine and Busulphan (70 days) groups the weight of the organ was within normal range. However, the prostatic acid phosphatase activity recorded a decline only in Busulphan-fed animals particularly at 30 and 40 days; at 70 days there was a relative increase.

None of the compounds had any significant effect on weight and gonadotrophin content of the pituitary (Table 1). This was also true of the serum gonadotrophin level except in the Tretamine and Busulphan (40 days) groups in which a reduction was recorded (versus controls, $P<0.01$ ). The reduction was about $13 \%$ in the Tretamine-treated animals and $15 \%$ in the Busulphan group. 
PI.ATE 1

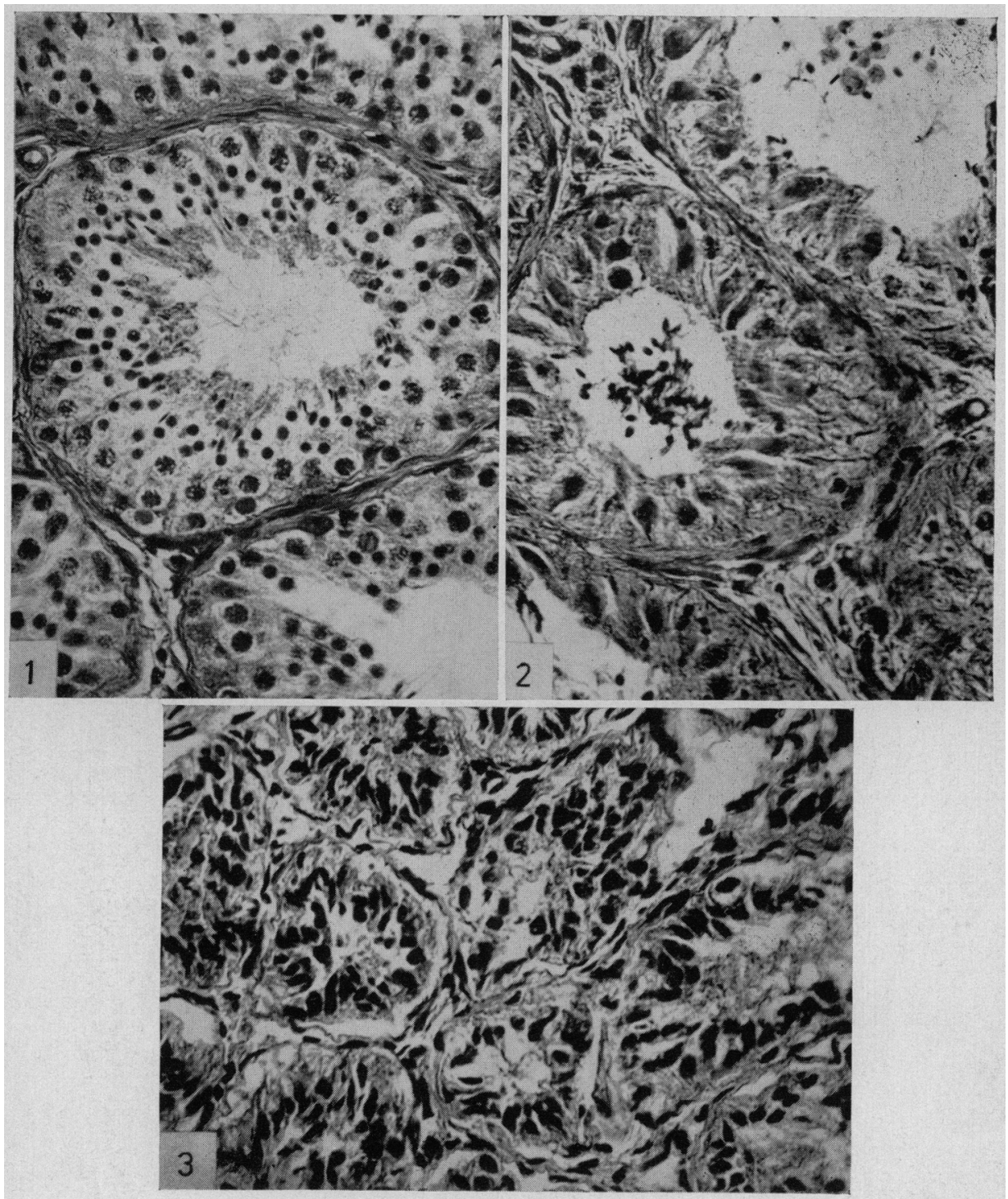

Fic. 1. The testis of a control monkey (Cil). Note normal features. $\times 350$.

Fir. 2. The testis of a Tretamine-treated monkey (T2). Note spermatogenic arrest at the spermatogonial stage. The interstitium is normal. $\times 350$.

Fro. 3. The testis of a monkey (B4) 40 days after Busulphan injection. Note severe reduction in tubular diameter and arrest of spermatogenesis at the spermatogonial stage. In the interstitium a preponderance of fibroblast-like cells is a feature. $\times 350$. 


\section{DISCUSSION}

The results of the present study show that chemical agents like Methallibure, Tretamine and Busulphan reported to influence male reproduction in nonprimate species (Paget et al., 1961; Bock \& Jackson, 1957; Steinberger et al., 1959; Jackson et al., 1961), do indeed exert one or the other type of effect on the genital organs of male rhesus monkeys.

At the dose level employed in this study $(16 \mathrm{mg} / \mathrm{kg})$, Methallibure is apparently without any effect on testis weight or histology and pituitary gonadotrophic activity. However, the weight of the accessory genital organs is reduced but no noteworthy alterations in fructose level and acid phosphatase activity are observed. In the rat the same dose given for about the same period causes a depression in seminal vesicle and ventral prostate weight without exerting any effect on the testis (Paget et al., 1961). On the other hand, even lower doses administered for longer periods cause spermatogenic suppression, decrease in weight of the accessory genital organs and a reduction in pituitary gonadotrophin content (Nelson \& Patanelli, 1965). It thus appears that the duration of treatment rather than dose is critical for the antispermatogenic efficacy of this compound.

Such loss of weight of the accessory genital organs unaccompanied by any apparent changes in Leydig cells or pituitary gonadotrophic function, would suggest a peripheral anti-androgenic effect of Methallibure in the species under study. However, caution has to be exercised in making such an assumption, since more sensitive indices of androgen action, like the vesicular fructose level and prostatic acid phosphatase activity (Albert, 1961), do not reveal any appreciable alteration after Methallibure treatment.

The nature of histological changes in the testis of the rhesus monkey after Tretamine administration is comparable to those reported for rats given high doses of this compound (Steinberger et al., 1959). Spermatogenesis is arrested at the spermatogonial stage and the subsequent stages are depleted by maturation. The effect is selective since androgenic function of the testis is not disturbed. It is pertinent to note that small intravenous doses of the compound disturb spermatogenesis in dogs (Hendry et al., 1951).

Tretamine does not alter the total gonadotrophin content of the pituitary but serum gonadotrophin level is reduced. This suggests a disturbance in release of gonadotrophin from the pituitary. However, since the reduction in serum gonadotrophin is of a low order $(13 \%)$ and considering the small number of animals employed in this study, it is difficult to infer whether an interference with pituitary gonadotrophic activity is actually involved in the mode of action of Tretamine in this species. If this is the case, then it is conceivable that the release of FSH rather than ICSH is reduced because androgenic function of the testis continues unhampered.

The nature and sequence of antispermatogenic effect of Busulphan in rhesus monkeys are, again, closely similar to those observed in rats (Jackson et al., 1961). Spermatogonial development is inhibited and the seminiferous elements are depleted by maturation between 30 and 40 days after treatment; at 70 days there is indication of repopulation of the tubules. However, a notable difference 
from rats is the depressive effect on the accessory genital organs presumably resulting from a disturbance in androgenic function of the testis; in the interstitium many atrophied Leydig cells are observed. Further, at 70 days there are clear indications of recovery of the interstitium and the accessory genital organs. It thus appears that unlike rats, the effect of Busulphan is not confined to the spermatogenic process in rhesus monkeys.

In a recent study, it has been shown that Busulphan evokes significant changes in the biochemical composition of the rat seminiferous tubules; the total gonadotrophin content of the pituitary is also consistently reduced (Kar et al., 1968). It has been suggested that the compound exerts its antispermatogenic effect by altering the metabolism of the tubules and disturbing the pituitary gonadotrophic activity. In rhesus monkeys, however, there is no change in total gonadotrophin content of the pituitary, but at 40 days post-injection there is some reduction in serum gonadotrophin level $(15 \%)$. An interference with the release of pituitary gonadotrophins is indicated which may be involved in the modus operandi of Busulphan in this species. However, further studies with larger numbers of animals are necessary to substantiate this view.

\section{ACKNOWLEDGMENTS}

This investigation was supported by grants from the Ford Foundation and the Indian Council of Medical Research. The authors wish to thank Dr M. L. Dhar for his interest in this study. Grateful acknowledgment is made to $\mathrm{Dr} \mathrm{A}$. L. Walpole, Imperial Chemical Industries, Alderley Park, Cheshire, for the gift of Methallibure and Tretamine; and Dr H. Jackson, Department of Experimental Chemotherapy, Christie Hospital, Manchester, for the supply of Busulphan. Thanks are due to Mr S. K. Nath for the photomicrographs.

\section{REFERENCES}

Ahrquist, K. A. (1966) Enzyme changes in the rat testis produced by the administration of Busulphan and of 7,12-dimethylbenz ( $\alpha$ ) anthracene. F. Reprod. Fert. 12, 377.

AlBert, A. (1961) The mammalian testis. In: Sex and Internal Secretions. Vol. 1, p. 305. 3rd edn. Ed. W. G. Young. Williams \& Wilkins, Baltimore.

Bock, M. \& JAckson, H. (1957) The action of triethylenemelamine on the fertility of male rats. Br. F. Pharmat. Chemother. 12, 1.

Hawk, P. B., Oser, B. L. \& Summerson, W. H. (1954) Practical physiological chemistry. McGraw-Hill, New York.

Hendry, J. A., Homer, R. F., Rose, F. L. \& Walpole, A. L. (1951) Cytotoxic agents. III. Derivatives of ethyleneimine. Br. F. Pharmac. Chemother. 6, 357.

Jackson, H., Fox, B. W. \& Graig, A. W. (1961) Antifertility substances and their assessment in the male rodent. F. Reprod. Fert. 2, 447.

KaR, A. B. \& DATtA, J. K. (1965) Induced hyperthyroidism and sexual development in prepuberal female rhesus monkeys. Archs Anat. microsc. Morph. exp. 54, 119.

Kar, A. B., Jehan, Q., Kamboj, V. P., Chowdhury, S. R. \& Chowdhury, A. R. (1968) Effect of Busulphan on biochemical composition of the rat seminiferous tubules. Indian F. exp. Biol. 6, (in press).

ManN, T. (1946) Fructose as a normal constituent of seminal plasma. Site of formation and function of fructose in semen. Biochem. $\mathbf{7 . 4 0 , 4 8 1 .}$

Nelson, W. O. \& Patanel.ri, D. J. (1965) Chemical control of spermatogenesis. In: Agents Affecting Fertility. Biol. Council Symp. p. 78. Eds. C. R. Austin and J. S. Perry. Churchill, London.

Paget, G. E., Walpole, A. L. \& Rrchardson, D. N. (1961) Non-steroid inhibitors of pituitary gonadotrophic function. Nature, Lond. 23, 1191.

Steinberger, E., Nelson, W. O., Boccabella, A. \& Dixon, W. J. (1959) A radiomimetic effect of triethylenemelamine on reproduction in the male rat. Endocrinology, 65, 40.

WALPOLE, A. L. (1965) Non-steroidal agents inhibiting pituitary gonadotrophic function. In: Agents Affecting Fertility. Biol. Council Symp. p. 159. Eds. C. R. Austin and J. S. Perry. Churchill, London. 